\title{
Prevention of Incidence of Corky Tissue Disorder in Sapota cv. Cricket Ball Fruits by Preharvest Spray Treatment
}

\section{S Shivashankar* and M Sumathi}

ICAR-Indian Institute of Horticultural Research, Bengaluru, Karnataka, India

*Corresponding Author: S Shivashankar, ICAR-Indian Institute of Horticultural Research, Bengaluru, Karnataka, India.

Received: June 19, 2019; Published: June 24, 2019

DOI: 10.31080/ASAG.2019.03.0542

\begin{abstract}
Corky tissue is a major physiological disorder accounting for deterioration of quality in ripe fruits of sapota cv. Cricket ball. The disorder takes a heavy toll in summer months resulting in huge losses of yield and fruit quality. Loss of seed viability during the early stages of fruit growth has been found to cause the disorder. Based on this finding, a method to prevent the incidence of the disorder by a simple pre-harvest treatment is described in this paper. Spray treatment of developing fruits and canopy with the spray formulation during period of drought stress was found to be highly effective in preventing the malady. The treated fruits were free from corky tissue with longer shelf life, higher TSS, increased mineral content and better health promoting properties. The method could be used to produce superior, export quality sapota fruits from orchards raised under both irrigated and rainfed conditions.
\end{abstract}

Keywords: Sapota cv. Cricket Ball; Corky Tissue; Pre-Harvest Treatment; Control Strategy

\section{Introduction}

A major constraint for the commercial production of superior quality of fruits of cv. Cricket Ball under rain-fed conditions is the incidence of the physiological disorder known as Corky Tissue (CT) with the rate of occurrence as high as $80 \%$ during summer [1]. Corky tissue of sapota is characterized by partially desiccated pulp with a hard lump occurring close to the skin of the ripe fruit and is rather sour to taste [2]. In the advanced stages of the malady, corky tissue adversely affects the edible quality making the fruit unfit for consumption (Figure 1). Past studies by us had established that the initiation of reverse flow from developing fruit to shoot due to poor seed viability led to the development of corky tissue symptoms [2]. Based on this finding, preharvest treatments were undertaken to prevent corky tissue incidence.

\section{Materials and Methods}

Materials

Field studies were carried out during 2015 on twenty-yearold Sapota trees of cv. Cricket ball planted at a spacing of $6 \times 6$ $\mathrm{m}$ and maintained under rain-fed conditions following standard package of practices. The experimental site was characterized by a mild tropical climate and a mean annual rainfall of $800 \mathrm{~mm}$ from July-November. The soil type in the experimental site was a red

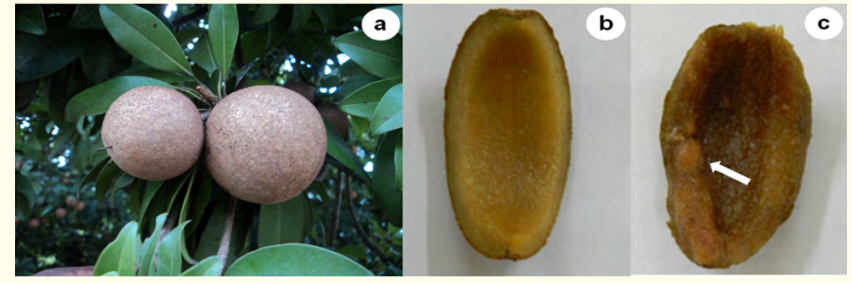

Figure 1: Picture showing (a) sapota cv. cricket ball, (b) cross section of healthy and (c) corky tissue affected sapota fruits. The white arrow indicates the presence of a hard lump of corky tissue deep inside the pulp close to the skin.

loam with a $\mathrm{pH}$ of 6.7. One set of 10 trees was maintained under rain-fed conditions (Control) while a second set of 10 trees were treated with the spray formulation (Table 1 ). The young and actively growing shoots along with developing fruits were treated four times with the spray formulation mixed with the All Purpose Spray Adjuvant (APSA, Amway Corporation, USA) $\left(0.3 \mathrm{ml} \mathrm{l}^{-1}\right)$ at 10-day intervals during the period of drought stress.

\section{Fruit samples}

Fruits were harvested at full maturity and ripened under ambient conditions of temperature $\left(25 \pm 2^{\circ} \mathrm{C}\right)$ and relative humidity $(70$ 
$\pm 5 \%$ ). Fully mature ripe fruits were cut open and the CT-affected fruits were identified based on the presence of hard lumps within the pulp close to skin [2]. The percent incidence of corky tissue was determined based on visual scoring of 100 ripe fruits from each treatment after cutting them open. Fruit diameter was calculated based on the circumference.

Total soluble solids (TSS)

TSS $\left({ }^{\circ} \mathrm{B}\right)$ was determined using a refractometer.

\section{Total phenol}

Total phenols were estimated following Singleton and Rossi [3] using gallic acid as standard and expressed as mg gallic acid equivalents $100 \mathrm{~g}^{-1} \mathrm{FW}$.

\section{Total flavonoids}

Total flavonoids were determined according to Kim., et al. [4] using catechin as standard. The content of flavonoids was expressed as mg catechin equivalents $\mathrm{g}^{-1} \mathrm{FW}$ of sample tissue.

\section{Ferric reducing anti-oxidant power (FRAP)}

FRAP was estimated following Benzie and Strain [5], based on the increase in absorbance at $593 \mathrm{~nm}$. The anti-oxidant capacity of each sample, based on its ability to reduce ferric ions, was expressed as the ascorbic acid equivalent anti-oxidant capacity (AEAC; in mg ascorbic acid $100 \mathrm{~g}^{-1} \mathrm{FW}$ of tissue), where the reducing power of a $1.0 \mathrm{mg}$ sample was equivalent to the reducing power of 1 nmole ascorbic acid.

\section{2, 2-diphenyl-1-picrylhydrazyl (DPPH) radical scavenging activity}

DPPH activity was assayed according to Brand Williams., et al. [6], with some modifications. A sample $(0.2 \mathrm{ml})$ of an $80 \%(\mathrm{v} / \mathrm{v})$ methanolic extract of each fruit tissue was mixed with $0.3 \mathrm{ml} 10$ $\mathrm{mM}$ acetate buffer, pH 5.4 and $2.5 \mathrm{ml} 0.008 \%$ (w/v) DPPH in $100 \%$ $(\mathrm{v} / \mathrm{v})$ methanol. The mixture was incubated at room temperature $\left(30^{\circ} \mathrm{C}\right)$ for $30 \mathrm{~min}$, followed by measurement of the absorbance at $517 \mathrm{~nm}$. DPPH scavenging activity was expressed as mg ascorbic acid equivalents $\mathrm{g}^{-1} \mathrm{FW}$ of sample tissue.

\section{Electrical conductivity}

Electrical conductivity was measured on pulp tissue $(1 \mathrm{~g})$ suspended in $10 \mathrm{ml}$ of distilled water using a conductivity bridge (ELICO model CM-180) and expressed as $\mathrm{dS} \mathrm{m}^{-1}$.

\section{Lipid peroxidation}

Lipid peroxidation was monitored by measuring the conversion of lipids to malondialdehyde (MDA), using the thiobarbituric acid reactive substances (TBARS) assay, as described by Draper and Hadley [7]. TBARS reagent $(1 \mathrm{ml})$ was added to a $0.5 \mathrm{ml}$ aliquot of tissue homogenate and heated for $20 \mathrm{~min}$ at $100^{\circ} \mathrm{C}$. The antioxidant, butylated hydroxy-toluene, was added before heating the samples. After cooling on ice, samples were centrifuged at $840 \mathrm{~g}$ for $15 \mathrm{~min}$ and absorbance of the supernatant was read at $532 \mathrm{~nm}$. Blanks for each sample were prepared and assessed in the same way to correct for the contribution of $A_{532}$ to the sample. TBARS results were expressed as MDA equivalents using 1,1,3,3- tetraethoxypropane as standard.

\section{Organic acids}

Organic acids were determined using a HPLC method with diode array detector described by Suárez., et al. [8] with slight modifications. Organic acids of sapota pulp samples were extracted in distilled water $(1: 10, \mathrm{w} / \mathrm{v})$, clarified by centrifugation at $3150 \times \mathrm{g}$ for 10 minutes and the supernatant was membrane filtered 0.45 $\mu \mathrm{m}$ ) before injection.

Organic acids were analyzed by Shimadzu LC-10 AD VP high performance liquid chromatography (HPLC) system equipped with quaternary pump, autosampler, and diode array detector with Zorbax SB-Aq C18 column (150 mm × $4.6 \mathrm{~mm}$ ID, $5 \mu \mathrm{m}$ ) (Agilent Technology, Santa Clara, CA. USA). Chromatographic separation was performed at $25^{\circ} \mathrm{C}$ at a flow rate of $0.4 \mathrm{ml} / \mathrm{min}$ using $1 \%$ potassium dihydrogen phosphate (KH2PO4, pH 2.5) as the mobile phase. Absorbance of the eluate was measured at $214 \mathrm{~nm}$ and the quantity of each organic acid was calculated using calibration curves prepared using $10 \mu \mathrm{L}$ each of the standard (Sigma, St. Louis, MO, USA) and

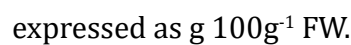

\section{Fatty acids}

Lipids from fruit tissue were extracted in a mixture of chloroform-methanol $(2: 1 \mathrm{v} / \mathrm{v})$ and the chloroform phase containing the lipids was separated, dried in a rotary vacuum evaporator at $40^{\circ} \mathrm{C}$ and stored at $-20^{\circ} \mathrm{C}$ until further used [9]. The extracted lipids were methylated by dissolving in methanol and refluxed for 10 min at $70^{\circ} \mathrm{C}$, followed by addition of $14 \% \mathrm{BF} 3$ in methanol. The mixture was further refluxed for $30 \mathrm{~min}$ at $70^{\circ} \mathrm{C}$ according to the modified method of Morrison and Smith [10]. Methyl esters of fatty acids (FAME) were subsequently extracted in heptane and dried on anhydrous sodium sulfate and filtered through $0.2 \mu \mathrm{m}$ nylon membrane. GC-FID analysis of fatty acid methyl esters was carried out using a Varian-3800 Gas chromatograph system equipped with flame ionization detector (FID) on a fused silica capillary column (VF-5 Factor Four, Lake Forest, CA, USA), $30 \mathrm{~m} \times 0.25 \mathrm{~mm}$ i.d and $0.25 \mu \mathrm{m}$ film thickness. The temperature program for the column was as follows: Initial oven temperature was set to $100^{\circ} \mathrm{C}$ for 4 min, increased @ $3^{\circ} \mathrm{C}$ per min up to $220^{\circ} \mathrm{C}$ and held for 4 min. The temperature was further increased to $260^{\circ} \mathrm{C}$ at the rate of $5^{\circ} \mathrm{C}$ per $\mathrm{min}$ and held for $10 \mathrm{~min}$. Injector and detector temperatures were maintained at $250^{\circ} \mathrm{C}$ and $260^{\circ} \mathrm{C}$ respectively. Helium at a flow rate of $1 \mathrm{ml} \mathrm{min}{ }^{-1}$ was used as the carrier gas. Flow rates of $\mathrm{H} 2$ and air 


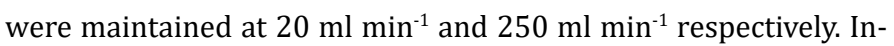
jection was initially done in split-less mode followed by split mode (1:30) after 1.5 minutes.

GC-MS analysis was performed on Varian-3800 gas chromatograph coupled with Varian 4000 GC-MS-MS ion trap mass selective detector. Fatty acids were separated on VF-5MS fused silica capillary column (Varian, USA) (30 m $\times 0.25 \mathrm{~mm}$ id with $0.25 \mu \mathrm{m}$ film thickness) by applying the same temperature program as described above for GC-FID analysis. The carrier gas was helium at a

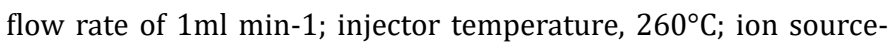
temperature, $220^{\circ} \mathrm{C}$; trap temperature, $200^{\circ} \mathrm{C}$ and transfer line temperature, $260^{\circ} \mathrm{C}$. Mass detector conditions were: EI-mode at 70 $\mathrm{eV}$ with full scan range, 50-450 amu. Fatty acids were identified by comparing the relative retention times of FAME peaks with those of reference standards (Sigma-Aldrich, USA) and also by comparing the spectra with those available in Wiley and NIST-2007 spectral libraries [11]. The total quantity of FAME was estimated as the sum of all GC-FID peak areas in the chromatogram and individual compounds were quantified by comparing the known individual FAME procured as standard. All the analyses were performed on three samples run separately.

\section{Minerals}

Nitrogen was determined by titrimetry after Kjeldahl digestion [12]. For the determination of other nutrient elements, dry tissue was digested with nitric acid-perchloric acid (9:4) mixture. Phosphorous, potassium, $\mathrm{Fe}, \mathrm{Mn}, \mathrm{Cu}$ and $\mathrm{Zn}$ were estimated according to Jackson [12] and $\mathrm{Ca}$ and $\mathrm{Mg}$ according to Jones., et al. [13] using a Perkin Elmer A-Analyst-200 model atomic absorption spectrophotometer (Perkin Elmer, Waltham, MA, USA).

\section{Statistical analysis}

The experiment was laid out in a completely random block design with ten replications (single tree/ replication). Data are presented as means \pm standard error (SE). Differences between control and spray formulation treated samples were tested by student's t- test [14].

\section{Results and Discussion}

As a result of treatment with spray formulation (Table 1), the incidence of corky tissue was reduced significantly (5.1\%) compared to control fruits (50.0\%). Fruit quality parameters like, fruit weight, fruit diameter, total soluble solids (TSS), mineral content, antioxidant capacity, concentration of phytochemicals and shelf life were significantly higher in treated fruits compared to control. Ascorbic acid and fumaric acid concentrations, the levels of total phenols, total flavonoids and the contents of DPPH and FRAP showed a significant increase in treated fruits. Spray formulation also enhanced the content of USFA and reduced SFA content thereby altering the SFA/USFA ratio favourably (Table 2). The treated fruits recorded significantly higher contents of mineral nutrients such as, N, Ca, Mg, Fe, Zn, Mn and Cu compared to the control fruits (Table 3). Past studies had shown that under rain-fed system of cultivation, the phenomenon of "reverse flow" of water and nutrients from fruit to shoot occurred in sapota [1] associated with a higher rate of incidence of corky tissue. It was clearly evident that during water stress, the emerging shoots got higher priority for the available water compared to developing fruits resulting in a continuous drain of moisture from fruit to shoot [15]. Consequently, the reduction in moisture content of the pulp triggered a host of biochemical changes leading to the development of corky tissue in sapota characterized by partially dehydrated mesocarp tissue with plasmolyzed cells [1]. In the light of the above, it was clearly apparent that the reduction in the rate of incidence of corky tissue from $50.0 \%$ in control to $5.1 \%$ in fruits treated with spray formulation was the result of the cessation of reverse flow from fruit to shoot. Besides reducing the CT incidence, the spray formulation also improved the fruit quality characteristics. The significant improvement in fruit quality parameters by application of spray formulation showed that the biosynthetic processes leading to accumulation of minerals, TSS, antioxidants and bioactive compounds were enhanced by the treatment, consequently leading to higher fruit weight, fruit diameter and shelf life (Table 2). Similar results of improvement of fruit quality by foliar application have been reported in other fruit crops also [16]. The treated fruits showed a lower SFA/USFA ratio which is considered to play an important role in reducing plaque build-up in the arteries, reducing the risk of heart attack and stroke [17]. The three-fold increase of ascorbic acid content in treated fruits clearly showed that the antioxidant activity was significantly higher compared to control fruits. The treated fruit also had a higher proportion of fumaric acid, an intermediate of the Krebs' citric acid cycle, which is essential for energy production by cells. Studies with diet containing fumaric acid esters have shown an inhibition of proliferation of keratinocytes [18]. Therefore, treated fruits with a significantly higher concentration of fumaric acid might be used

\begin{tabular}{|l|c|c|c|c|c|c|c|c|c|c|c|}
\hline Mineral element & $\mathbf{N}$ & $\mathbf{P}$ & $\mathbf{K}$ & $\mathbf{C a}$ & $\mathbf{M g}$ & $\mathbf{F e}$ & $\mathbf{Z n}$ & $\mathbf{M n}$ & $\mathbf{C u}$ & $\mathbf{B}$ & EDTA \\
\hline $\mathrm{mg} \mathrm{l}^{-1}$ & 100 & 100 & 100 & 100 & 100 & 10 & 10 & 10 & 10 & 10 & 3 \\
\hline
\end{tabular}

Table 1: Composition of spray formulation. 


\begin{tabular}{|c|c|c|c|}
\hline Parameters & Control & Spray treated & $(P=0.05)$ \\
\hline Ascorbic acid (mg g $\left.{ }^{-1} \mathrm{FW}\right)$ & $0.12 \pm 0.02$ & $0.39 \pm 0.03$ & $* *$ \\
\hline Citric acid (mg g $\left.{ }^{-1} \mathrm{FW}\right)$ & $8.10 \pm 0.21$ & $7.86 \pm 0.10$ & $* *$ \\
\hline Fumaric acid $\left(\mathrm{mg} \mathrm{g}^{-1} \mathrm{FW}\right)$ & $0.04 \pm 0.005$ & $0.50 \pm 0.05$ & $* * *$ \\
\hline SFA (mg 100g $\left.{ }^{-1} \mathrm{FW}\right)$ & $4.56 \pm 0.21$ & $3.77 \pm 0.10$ & $* * *$ \\
\hline USFA (mg $\left.100 \mathrm{~g}^{-1} \mathrm{FW}\right)$ & $4.68 \pm 0.13$ & $8.45 \pm 0.42$ & $* * *$ \\
\hline SFA/USFA & $0.97 \pm 0.15$ & $0.45 \pm 0.05$ & $* *$ \\
\hline $\operatorname{TSS}\left({ }^{\circ} \mathrm{B}\right)$ & $15.56 \pm 1.21$ & $22.14 \pm 1.08$ & $* * *$ \\
\hline Total phenols (mg $100 \mathrm{~g}^{-1} \mathrm{FW}$ ) & $28.22 \pm 0.44$ & $41.43 \pm 0.94$ & $* * *$ \\
\hline DPPH (mg $100 \mathrm{~g}^{-1} \mathrm{FW}$ ) & $33.18 \pm 1.21$ & $50.02 \pm 2.04$ & $* *$ \\
\hline FRAP (mg $\left.100 \mathrm{~g}^{-1} \mathrm{FW}\right)$ & $30.27 \pm 1.11$ & $62.08 \pm 1.73$ & $* * *$ \\
\hline Total flavonoids (mg $100 \mathrm{~g}^{-1} \mathrm{FW}$ ) & $15.07 \pm 1.07$ & $28.11 \pm 1.54$ & $* * *$ \\
\hline Fruit weight (g) & $74.59 \pm 3.24$ & $152.22 \pm 7.11$ & $* * *$ \\
\hline Fruit diameter $(\mathrm{cm})$ & $4.9 \pm 0.10$ & $7.6 \pm 0.28$ & $* * *$ \\
\hline Fruit yield (kg/tree) & $47.64 \pm 2.57$ & $93.47 \pm 3.84$ & $* * *$ \\
\hline Electrical conductivity $\left(\mathrm{dS} \mathrm{m}^{-1}\right)$ & $0.79 \pm 0.07$ & $0.47 \pm 0.05$ & $* * *$ \\
\hline MDA $\left(\mu \mathrm{g} 100 \mathrm{~g}^{-1} \mathrm{FW}\right)$ & $4.69 \pm 0.20$ & $1.77 \pm 0.10$ & $* * *$ \\
\hline Shelf life (days) & $7.68 \pm 0.34$ & $11.31 \pm 0.79$ & $* * *$ \\
\hline CT incidence (\%) & $50.0 \pm 1.86$ & $5.1 \pm 0.62$ & $* * *$ \\
\hline
\end{tabular}

Table 2: Biochemical differences between control and treated fruits of sapota cv. Cricket ball (M $\pm \mathrm{SE})$. M: Mean. SE: Standard Error.

\begin{tabular}{|l|c|c|c|}
\hline \multirow{2}{*}{ Minerals } & \multicolumn{2}{|c|}{ Fruits } & \multirow{2}{*}{$(\boldsymbol{P}=\boldsymbol{0 . 0 5})$} \\
\cline { 2 - 3 } & Control & Spray treated & \\
\hline $\mathrm{N}(\%)$ & $0.11 \pm 0.012$ & $0.18 \pm 0.016$ & NS \\
\hline $\mathrm{P}(\%)$ & $0.03 \pm 0.002$ & $0.05 \pm 0.005$ & $*$ \\
\hline $\mathrm{K}(\%)$ & $2.41 \pm 0.091$ & $2.83 \pm 0.080$ & $*$ \\
\hline $\mathrm{Ca}(\%)$ & $0.41 \pm 0.031$ & $1.71 \pm 0.11$ & $* * *$ \\
\hline $\mathrm{Mg}(\%)$ & $0.16 \pm 0.024$ & $0.44 \pm 0.050$ & $*$ \\
\hline Fe (mg \%) & $18.67 \pm 0.233$ & $33.47 \pm 0.731$ & $* * *$ \\
\hline $\mathrm{Zn}(\mathrm{mg} \%)$ & $3.04 \pm 0.250$ & $3.31 \pm 0.174$ & NS \\
\hline $\mathrm{Mn}(\mathrm{mg} \%)$ & $1.89 \pm 0.083$ & $2.05 \pm 0.113$ & NS \\
\hline $\mathrm{Cu}(\mathrm{mg} \%)$ & $1.11 \pm 0.052$ & $2.10 \pm 0.201$ & $*$ \\
\hline
\end{tabular}

Table 3: Mineral elements in mature ripe fruits of sapota cv. Cricket ball $(M \pm S E)$.

NS= Not significant

M: Mean. SE: Standard Error.

as a dietary supplement to treat patients suffering from psoriasis. Considering the above results, it was clear that the treated fruits were superior to control fruits in their quality, nutritive value and the health benefitting properties.

\section{Conclusion}

To summarize, the results of the present study have demondtrated that spraying young and actively growing shoots and fruits with the spray formulation (Table 1) at 10-day intervals during the pe- 
riod of peak drought stress is effective in preventing CT incidence. Application of the formulation during the rainless summer months ensured production of high quality sapota fruits free from corky tissue and enriched with health promoting phyto-chemicals, antioxidants and essential mineral elements. This is world's first report showing that preharvest treatment of developing fruits could be gainfully applied to produce corky tissue-free fruits of consistently high quality, from rain-fed sapota trees, especially in those regions where the possibility of development of drought stress in summer is high. Since, foliar spray formulation is effective, efficient and easy to apply, it could also be used as an adjunct to conventional irrigation in an attempt to maximize productivity and quality of sapota fruits cv. Cricket ball on a commercial scale.

\section{Acknowledgements}

Authors thank the Director of the Institute for the support and Dr. H B.Raghupathi, Principal Scientist, Division of Soil science and Agricultural Chemistry, for help in the analysis of mineral elements.

\section{Bibliography}

1. Shivashankar S., et al. "The role of seed viability in development of corky tissue in sapota (Manilkara achras) fruit in India". The Journal of Horticultural Science and Biotechnology 88.5 (2013): 671-677.

2. Shivashankar S., et al. "Drought-stress-induced corky tissue formation in sapota fruit cv. Cricket ball is linked to enhanced reverse flow". Scientia Horticulturae 169 (2014): 20-26.

3. Singleton VL and Rossi JA. "Colorimetry of total phenolics with phosphomolybdic-phosphotungstic acid reagents". American Journal of Enology and Viticulture 16.3 (1965): 144-158.

4. Kim D 0., et al. "Quantification of polyphenolics and their antioxidant capacity in fresh plums". Journal of Agricultural and Food Chemistry 51.22 (2003): 6509-6515.

5. Benzie IF and Strain JJ. "The ferric reducing ability of plasma (FRAP) as a measure of antioxidant power. The FRAP assay". Analytical Biochemistry 239.1 (1996): 70-76.

6. Brand-Williams W., et al. "Use of a free radical method to evaluate antioxidant activity". Lebensmittel Wissenschaft und Technologie 28.1 (1995): 25-30.

7. Draper $\mathrm{HH}$ and Hadley M. "Malondialdehyde determination as an index of lipid peroxidation". Methods Enzymology 186 (1990): 421-431.
8. Suárez M H., et al. "Analysis of organic acid content in cultivars of tomato harvested in Tenerife". European Food Research and Technology 226.3 (2008): 423-435.

9. Folch J., et al. "A simple method for the isolation and purification of lipids in animal tissues". Journal of Biological Chemistry 226.1 (1957): 497-509.

10. Morrison WR and Smith LM. "Preparation of fatty acid methyl esters and dimethyl acetals from lipids with boron-fluoridemethanol". Journal of Lipid Research 5 (1964): 600-608.

11. Liu K. "Preparation of fatty acid methyl esters for gas chromatographic analysis of lipids in biological materials". Journal of the American Oil Chemists Society 71.11 (1994): 1179-1187.

12. Jackson ML. "Soil chemical analysis". Prentice Hall of India Private Limited, New Delhi, India (1973): 498.

13. Jones Jr JB., et al. "Plant analysis handbook". Micro-Macro Publishing Inc., Athens, GA (1991).

14. Panse VG and Sukhatme PV. "Statistical methods for agricultural workers". ICAR, New Delhi, India (1978): 108.

15. Shivashankar S., et al. "Influence of drought stress on the incidence of corky tissue in sapota". International Journal of Fruit Science 14.3 (2014): 297-310.

16. Arvind B., et al. "Foliar application of potassium, calcium, zinc and boron enhanced yield, quality and shelf life of mango". HortFlora Research Spectrum 1.4 (2012): 300-305.

17. Renata M and Mozaffarian D. "Saturated Fat and Cardiometabolic Risk Factors, Coronary Heart Disease, Stroke, and Diabetes: a Fresh Look at the Evidence". Lipids 45.10 (2010): 893905.

18. Zhu K and Mrowietz U. "Inhibition of dendritic cell differentiation by fumaric acid esters". Journal of Investigative Dermatology 116.2 (2001): 203-208.

Volume 3 Issue 7 July 2019 (C) All rights are reserved by $S$ Shivashankar and $M$ Sumathi. 